\title{
Diálogo entre programas de pós-graduação: Contribuições para uma investigação no ensino de ciências
}

Oliveira, Itamar S. $;^{1}$ Boccardo, Lilian²

Recibido: 16/12/2016

Aprobado: 30/12/2016

\section{Resumo}

Este artigo versa sobre as contribuições para uma investigação na área de Ensino de Ciências mediante a experiência de participação na missão de estudos entre os programas de Mestrado em Educação Científica e Formação de Professores (UESB / Brasil) e a Maestría en Didactica de Las Ciéncias Experimentales (UNL / Argentina). Inicialmente a intervenção foi realizada no Brasil com estudantes do Ensino Médio nas aulas de Biologia propondo-lhes problematizações referentes ao Ensino de Zoologia com base na Metodologia da Solução de Problemas e na Argentina foi realizada uma intervenção similar. Os resultados com estudantes argentinos conduziram os investigadores a reavaliar os dados iniciais, já que, mesmo considerando os diferentes contextos, apontaram problemas relacionados à ausência de competências linguísticas e deficiência relacionada à alfabetização científica dos estudantes brasileiros. A investigação não teve o objetivo fazer uma comparação entre os grupos, mas apontar caminhos para ações reflexivas que o intercâmbio proporcionou, cooperando para o estabelecimento de redes investigativas e ampliação do debate acerca do Ensino de Ciências.

Palavras-chave: Intercâmbio, Pós-Graduação, Ensino de Ciências.

\footnotetext{
${ }^{1}$ Colegiado de Ciências da Natureza, Universidade Federal do Vale do São Francisco - UNIVASF, Campus Serra da Capivara, Piauí, Brasil.soaresitamar@hotmail.com

2 Departamento de Ciências Biológicas, Universidade Estadual do Sudoeste da Bahia - UESB, Campus Jequié, Bahia, Brasil. Iboccardo@hotmail.com
} 


\section{Sumary}

This article discusses about contributions to a research in the area of Science Teaching through an experience of participation in the study mission between the Masterss degree Educação Científica e Formação de Professores (UESB / Brazil) and Master's degree Didactica de Las Ciéncias Experimentales (UNL / Argentina). Initially the intervention was realized in Brazil with the students of the High School in the classes of Biology, proposing to them the questions related to the Zoology Teaching based on the Methodology of the Solution of Problems and in Argentina a similar intervention was realized. The results with the Argentine students led the researchers to re-evaluate the initial data, since, even considering the different contexts, they point out problems related to the absence of language skills and deficiency related to the scientific literacy of the Brazilian students. The research didn't aim make a comparison between the groups, but to point ways to reflective actions about the interchange, cooperate to establish the research networks and to expand the debate on Science Teaching.

Keywords: Interchange, Post-Graduation, Science Teaching. 